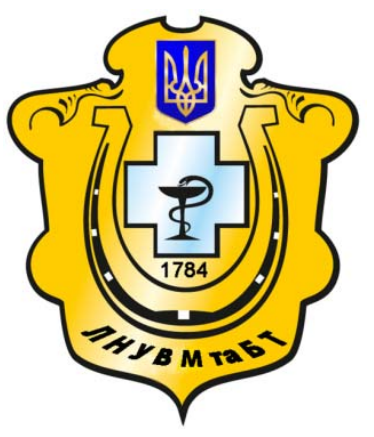

Науковий вісник Львівського національного університету ветеринарної медицини та біотехнологій імені С.3. Гжицького

Scientific Messenger of Lviv National University of Veterinary Medicine and Biotechnologies named after S.Z. Gzhytskyj

doi:10.15421/nvlvet7038

ISSN 2413-5550 print

ISSN 2518-1327 online

$\underline{\text { http://nvlvet.com.ua/ }}$

УДК 619:616.381-002:636.8

\title{
Патоморфологічні зміни легеневої тканини за інфекційного перитоніту котів
}

\author{
Г.І. Коцюмбас, В.В. Пріцак, М.Р. Халанія \\ galyna.kotsyumbas@gmail.com; vita77t@ukr.net; Pantera-m@i.ua
}

Львівський національний університет ветеринарної медиџини та біотехнологій імені С.3. Гжицького, вул. Пекарська, 50, м. Львів, 79010, Україна

\begin{abstract}
У статті представлені результати патологоанатомічних, патогістологічних та гістохімічних досліджень легеневої тканини за ексудативної форми спонтанного інфекиійного перитоніту котів. Отримані результати досліджень дозволили проаналізувати патологоанатомічні, мікроструктурні зміни в легеневій тканині котів та визначити механізм розвитку патологічного процесу, який призводить до летального наслідку.

Проведено патологоанатомічне дослідження трупів 4 котів: кота віком 3 роки та двох кішок віком 1 рік $і 2$ місяці та віком 1 рік і 5 місяиів з ознаками ексудативного плевриту; кішки віком 2 роки з вираженими ознаками ексудативного перитоніту та плевриту. Відібрано перитонеальну рідину та фрагменти легеневої тканини для ичитологічного і патогістологічного дослідження. За патологоанатомічного розтину виявлено накопичення у грудній, черевній порожнинах та у перикардіальному просторі мутного ексудату з пластівиями фібрину, потовщення серозних покривів, нашарування на них фібрину. За патогістологічного дослідження в легеневій тканині відзначали наслідки гемодинамічних порушень у вигляді периваскулярних множинних крововиливів, інтерстиціальну пневмонію, ателектатичні і емфізематозні осередки та ознаки фібринозного плевриту в стані організації. Найбільш важкі зміни розвивались в структурах судинної системи та характеризувались пошкодженням ендотелію судин, розвитком продуктивного мезо- і периартериїту, синдромом дисемінованого внутрімньосудинного згортання крові, стазами і гемолізом еритроцитів в дрібних судинах міжсальвеолярних перегородок. У легенях превалювала мононуклеарно-макрофагальна інфільтрачія, особливо в периартеріальній зоні, щуо вказувало на наявність продуктивно-некротичних васкулітів. Розвиток синдрому дисемінованого внутрішньосудинного згортання крові зумовив утворення в судинному руслі множинних мікротромбів, агрегованих клітин, наявність яких призвела до розвитку тромбозів, а згодом і геморагій. Блокада мікрочиркуляиії, в свою чергу, призвела до гіпоксії тканин, аџидозу та, як наслідок, дистрофічних змін в останніх. Виявлені процеси в судинній системі легеневої тканини зумовили незворотні зміни гомеостазу, різке зниження адаптаиійних можливостей і порушення трансорганного кровообігу.

Ключові слова: фібрин, периартериїти, гомеостаз, пневмонія, плеврит, патогістологічні, гістохімічні зміни, синдром десимінованого внутрішньосудинного згортання крові.
\end{abstract}

\section{Патоморфологические изменения легочной ткани при инфекционном перитоните кошек}

\author{
Г.И. Коцюмбас, В.В. Прицак, М.Р. Халания \\ galyna.kotsyumbas@gmail.com; vita77t@ukr.net; Pantera-m@i.ua
}

Львовский национальный университет ветеринарной медицины и биотехнологий имени С.3. Гжиикого, ул. Пекарская, 50, г. Львов, 79010, Украина

В статье представлены результаты патологоанатомических, патогистологических и гистохимических исследований легочной ткани за экссудативной формы спонтанного инфекиионного перитонита кошек. Полученные результаты исследований позволили проанализировать патологоанатомические, микроструктурные изменения в легочной ткани котов и определить механизм развития патологического процесса, который приводит к летальному исходу.

\section{Citation:}

Kotsiumbas, G., Pritsak, V., Khalaniia, M. (2016). Pathomorphological changes of the lung tissue with feline infectious peritonitis. Scientific Messenger LNUVMBT named after S.Z. Gzhytskyj, 18, 3(70), 161-166.

Scientific Messenger LNUVMBT named after S.Z. Gzhytskyj, 2016, vol. 18, no 3 (70) 
Проведено патологоанатомическое исследование трупов 4 котов: кота в возрасте 3 года та двоих кошек в возрасте 1 год и 2 месяия и в возрасте 1 год 5 месяцев с признаками экссудативного плеврита; кошки возрастом 2 года с выраженными признаками экссудативного перитонита и плеврита. Отобрано перитонеальную жидкость и фрагменть легочной ткани для изитологического и патогистологического исследования. При патологоанатомическом вскрытии обнаружено накопление в грудной, брюшной полостях и перикардиальном пространстве мутного экссудата с хлопьями фибрина, утолщение серозных оболочек, наслоения на них фибрина. При патогистологическом исследовании в легочной ткани отмечали последствия гемодинамических нарушений в виде периваскулярных множественных кровоизлияний, интерстициальную пневмонию, ателектатические и эмфизематозные очаги и признаки фибринозного плеврита в состоянии организации. Наиболее тяжелье изменения развивались в структурах сосудистой системы и характеризовались повреждением эндотелия сосудов, развитием продуктивного мезо- и периартерииту, синдромом диссеминированного внутрисосудистого свертывания крови, стазами и гемолизом эритроцитов в мелких сосудах межальвеолярных перегородок. В легких превалировала мононуклеарно-макрофагальная инфильтрация, особенно в периартериальной зоне, что указывало на наличие продуктивно-некротических васкулитов. Развитие синдрома диссеминированного внутрисосудистого свертывания крови вызывал образование в сосудистом русле множественных микротромбов, агрегированных клеток, наличие которых привели к развитию тромбозов, а впоследствии и геморрагий. Блокада микроциркуляции, в свою очередь, привела к гипоксии тканей, ацидоза и, как следствие, дистрофических изменений в последних. Обнаруженные процессы в сосудистой системе легочной ткани обусловили необратимые изменения гомеостаза, резкое снижение адаптационных возможностей и наруиения трансорганного кровообрашения.

Ключевые слова: фибрин, периартерииты, гомеостаз, пневмония, плеврит, патогистологические, гистохимические изменения, синдром диссеминированного внутрисосудистого свертывания крови.

\title{
Pathomorphological changes of the lung tissue with feline infectious peritonitis
}

\author{
G. Kotsiumbas, V. Pritsak, M. Khalaniia \\ galyna.kotsyumbas@gmail.com; vita77t@ukr.net; Pantera-m@i.ua \\ Lviv national university of veterinary medicine and biotechnologies named after S. Gzhytskyj, \\ Pekarska Str., 50, Lviv, 79010, Ukraine
}

\begin{abstract}
The article presents the results of pathoanatomical, pathohistological and histochemical researches of the lung tissue for exudative form of the spontaneous infectious peritonitis of cats. The results of researches allow us to analyze pathoanatomical, microstructural changes in lung tissue of cats in various forms of peritonitis infectious and to define the mechanism of the pathological process that cause lethal consequence.
\end{abstract}

The pathoanatomical research of dead bodies of 4 cats has been carried out: a 3 year-old cat and 1 year and 2 month-old cat and 1 year and 5 month-old with symptoms of exudative pleurisy; a 2 year-old cat with clear signs of exudative peritonitis and pleurisy. Peritoneal fluid and lung tissue fragments for cytological and pathohistological examination were selected. At pathoanatomical autopsy accumulation in the thoracal, abdominal cavities and pericardial space fluid with the flakes of fibrin were revealed, thickening of the serous membranes, layering them fibrin. At the pathohistological research in lung tissue noted the consequences of hemodynamic disturbances in the form of multiple perivascular hemorrhage, interstitial pneumonia, atelectasis and emphysematous cells and signs of fibrinous pleurisy in the state organization have been noted. The hardest changes were developed in the structures of the vascular system and are characterized by the damage of vascular endothelium, the development of productive meso- and periarteritis, syndrome of disseminated intravascular coagulation, stasis and hemolysis of erythrocytes in small vessels of interalveolar septum leading to the oppression of hemocirculation. In lungs, the mononuclear-macrophage infiltration prevailed, especially in periarteritis zone, indicating the presence of productively-necrotic vasculitis. The development of the syndrome disseminated intravascular coagulation led to the formation of multiple micro-blood clots, aggregated cells in vascular channel, the presence of which has led to the development of thrombi and then hemorrhages. The blockade microcirculation, in their turn, led to tissue hypoxia, acidosis and, as a result, distrophic changes in the past. The discovered processes in the vascular system of the lung tissue caused the insufficient flow of blood, irreversible changes of homeostasis and a sharp decline in adaptive capacity.

Key words: fibrin, periarteritis, homeostasis, pneumonia, pleurisy, pathohistological, histochemical changes, syndrome of disseminated intravascular coagulation.

\section{Вступ}

Інфекційний перитоніт котів (Feline Infection Peritonitis, інфекційне запалення очеревини котів, FIP, ІПК) - вірусне захворювання тварин родини Felidae. Вперше захворювання з клінічними ознаками перитоніту було описано у котів вченими Wolfe i Griesemer у 1960 році в Сполучених Штатах Америки. Вчені вважають, що захворювання кішок спричиняють слабо патогенні (ККВК) та високопатогенні (ВІПК) штами коронавірусу. Слабопатогенні штами вірусу викликають ентерит і легкий перебіг хвороби, тварина видужує. Високопатогенні штами вірусу (ВІПК) появляються внаслідок мутації слабопатенних (ККВК) штамів вірусу в організмі тварини і зумовлюють повіль- ний перебіг хвороби та високу смертність (Benetka et al., 2004; Hartmann, 2005; Goodson et al., 2009; Gyl'mutdynov et al., 2010). Є повідомлення про трансплацентарну передачу інфекції від матері кошенятам. У 1966 p. Montali встановив, що хвороба, викликана коронавірусом може проявлятись у двох клінікоанатомічних формах: сухій та вологій (ексудативній). Обидві форми викликають стійкі морфологічні зміни внутрішніх органів та призводять до летального висліду (Pedersen, 1995; Sparkes et al., 2004).

Згідно опрацьованих джерел вітчизняних та зарубіжних авторів (Hartmann, 2005; Pedersen, 1995; Sparkes et al., 2004) трапляється мало робіт з висвітлення патогенезу даного захворювання та вивчення патоморфологічних, а особливо гістологічних та гіс- 
тохімічних змін в органах і тканинах за інфекційного перитоніту котів.

Метою роботи було дослідити патологоанатомічні та мікроструктурні зміни в легеневій тканині котів за ексудативної форми інфекційного перитоніту та визначити деякі аспекти механізму розвитку патологічного процесу.

\section{Матеріал і методи досліджень}

Проведено патологоанатомічне дослідження трупів 4 котів, у яких прижиттєво було діагностовано ІПК (сироватки крові методом ІФА): кота віком 3 роки з ознаками плевриту; кішки віком 2 роки з вираженими ознаками перитоніту та плевриту; кішки, віком 1 рік і 2 місяці та віком 1 рік 5 місяці - плевриту (Zon et al., 2009). Відібрали перитонеальну рідину для цитологічного та фрагменти легеневої тканини для патогістологічного дослідження. Перитонеальну рідину відцентрифуговували при 2000 об/хв, 3 осаду виготовляли мазки, які висушували на повітрі з наступною дофіксацією метиловим спиртом протягом 5-10 хв і фарбували за методом Романовського-Гімза та проглядали під світловим мікроскопом на різних збільшеннях. Фрагменти легеневої тканини розміром $1 \times 1$ см фіксували у 10\% нейтральному розчині формаліну, зневоднювали у спиртах зростаючої міцності та заливали розплавленим парафіном. Із парафінових блоків виготовляли гістологічні зрізі на санному мікротомі МC-2, товщиною 7 мкм, які фарбували гематоксиліном та еозином, та за методами: Ван-Гізон (1889), Стідмена (1950), Зербіно-Лукасевич (1984) за загальноприйнятими методиками (Merkulov, 1969; Goral's'kyj et al., 2011; Zerbino and Lukasevich, 1984).

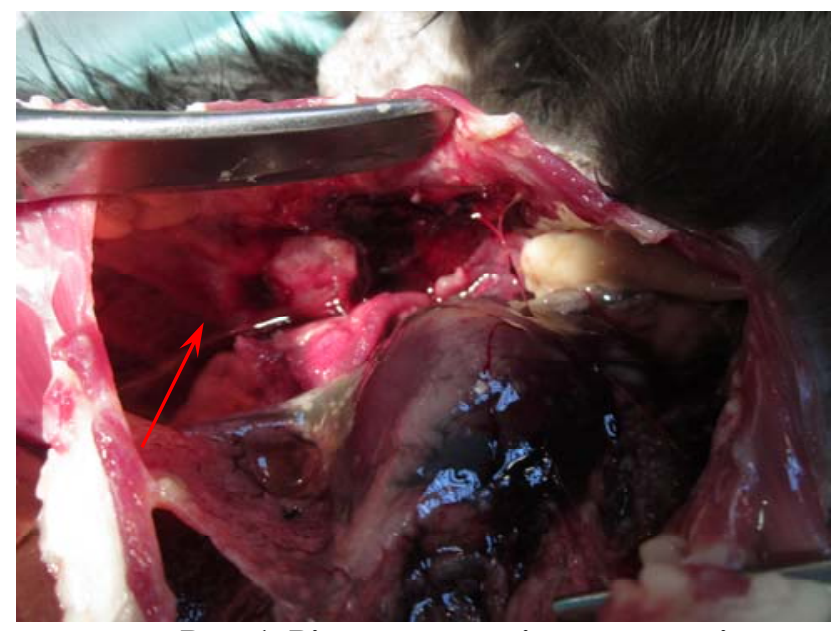

Рис. 1. Рідина в грудній порожнині

За гістологічного дослідження на легеневій плеврі відзначали масивні напластування фібрину, які частково піддавались процесам організації. Фібринозні маси з боку легеневої плеври були інфільтровані фібробластами, пронизані ретикулярними і колагеновими волокнами і густо заповнені новоутвореними мікросудинами. У верхівковій долі легень фібрин був неорганізований, у клітинному складі серед фібринозних мас переважали макрофаги, місцями відзначали осе-
Готові препарати розглядали під світловим мікроскопом Leica DM-2500 (Switzerland), фотографували їх фотокамерою Leica DFC450C з програмним забезпеченням Leica Application Suite Version 4.4.

\section{Результати та їх обговорення}

На розтині трупів котів патологоанатомічні зміни були дещо схожими. Відзначали накопичення переважно у черевній, менше в грудній порожнинах та перикардіальному просторі напівпрозорої або мутнуватої рідини. У грудній та черевній порожнинах вміст рідини від світло-жовтого до червоного кольору, в'язкої з домішками пластівців фібрину. На серозних оболонках - фібрин з сірим відтінком. За мікроскопії мазків з відібраної та відцентрифугованої перитонеальної рідини виявляли нейтрофіли, лімфоцити, макрофаги і мезотеліальні клітини.

У двох котів відзначали помірні фібринозні нашарування на костальній, легеневій плеврах та на перикарді, в інших двох - крім костальної та легеневих плевр ще помірні сіруваті пластівці та нитковидні структури спостерігали на очеревині та селезінці. Візуально легенева плевра переважно тьмяна, потовщена, нерівномірно вкрита сірими нашаруваннями фібрину, які щільно утримувались на поверхні (рис. 1). В одного кота була наявна червонувата рідина в грудній порожнині. Місцями виявляли жовтуваті напластування на костальній плеврі. На перикарді помітними були осередки жовто-білих напластувань, різних розмірів (рис. 2). Очеревина матова, потовщена 3 помірними сірувато-жовтими напластуваннями, а кровоносні судини брижі розширені, заповнені кров'ю.

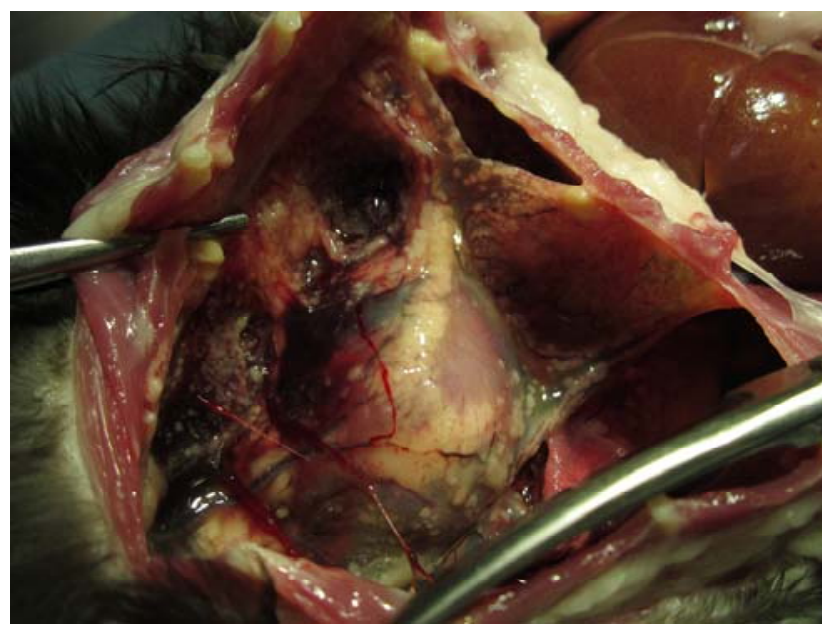

Рис. 2. Грудна порожнина. Масивне фібринозне нашарування на плеврі та перикарді

редки заповнені нейтрофілами (рис. 3). Макрофаги, переважно були гіпертрофовані, а в їх цитоплазмі часто знаходились оксифільні включення. У легеневій тканині реєстрували розвиток інтерстиціальної пневмонії, яка чергувалась 3 ділянками ателектазу та емфіземи. Емфізематозні ділянки характеризувались розширенням просвіту альвеол, витонченням, а місцями розривом їх стінок і порушенням еластичних волокон. 


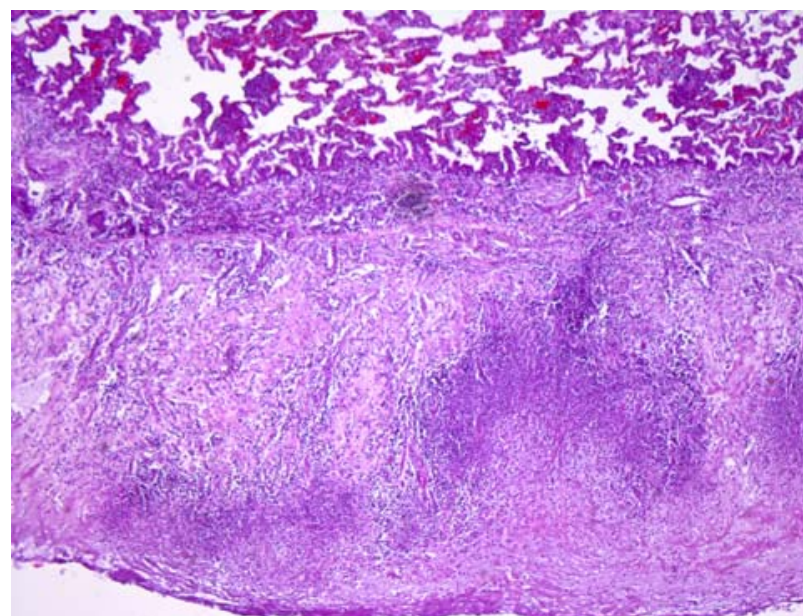

Рис. 3. Фібринозний плеврит легеневої плеврит верхівкових долей легень. Гематоксилін та еозин. Ок.10, об. 10

Міжальвеолярні перегородки витончувались і збіднювались капілярами (рис. 4).

На важкість мікроструктурних змін вказували різко виражені циркуляторні розлади з вираженою периваскулярною клітинною інфільтрацією, а також порушення стінок та дистрофічно-некробіотичні зміни епітелію та стінок бронхів усіх калібрів. У деяких сегментарних бронхах і бронхіолах простежувалась десквамація клітин епітеліального покриву. Епітелій слизової оболонки бронхіол набряклий, 3 помірним вмістом кислих глікозаміногліканів, просвіт звужений, заповнений ексудатом. У субепітеліальному шарі лімфогістіоцитарна інфільтрація. Разом 3 тим відзначали в інших бронхах дилатацію, витончення стінки і порушення циркулярного шару м'язової оболонка

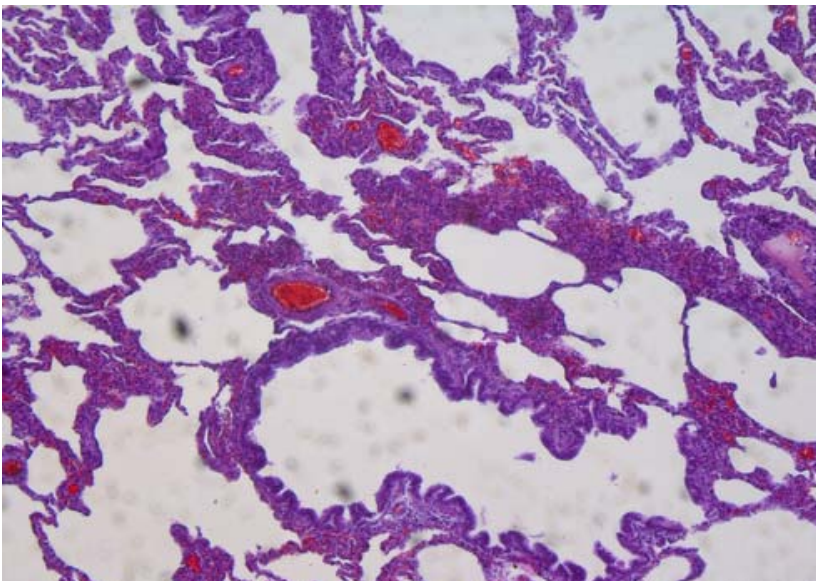

Рис. 5. Помірна дилатація бронхіоли. Гематоксилін та еозин. Ок.10, об. 10

В одних артеріолах ендотелій набряклий, цитоплазма просвітлена, клітини місцями десквамовані, в інших - відзначали десквамацію ендотелію та значне пошкодження базальної мембрани.

Відомо, що ендотеліальні клітини розміщені на межі циркулюючої крові і тканинами, що робить їх найбільш вразливими при дії різних патогенних чинників. Саме ці клітини контролюють місцеві процеси

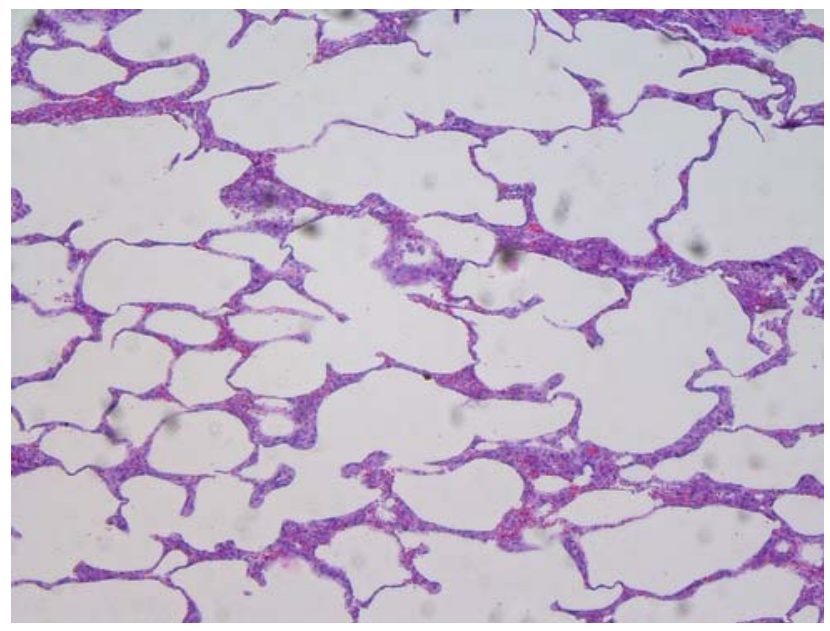

Рис. 4. Легені. Емфізематозні ділянки.

Гематоксилін та еозин. Ок.10, об. 20

(рис. 5). В інших ділянках виявляли значно потовщені стінки бронхів, де за тонким шаром циркулярних м'язів стінки простежувалась гіперплазія серомукозних бронхіальних залоз, багатих на кислі глікозаміноглікани (рис. 6).

Кровонаповнення судин переважно виражено у капілярах і венулах сполучнотканинних перегородок легень. У просвіті дрібних судин міжальвеолярної перегородки виявляли стази, гемолізовані еритроцити та плазму (рис. 7). Розширення посткапілярних венул супроводжувалось помітним депонуванням крові у венозному басейні. По ходу багатьох гілок легеневої артерії реєстрували розвиток продуктивного запалення $з$ утворенням неспецифічних гранульом.

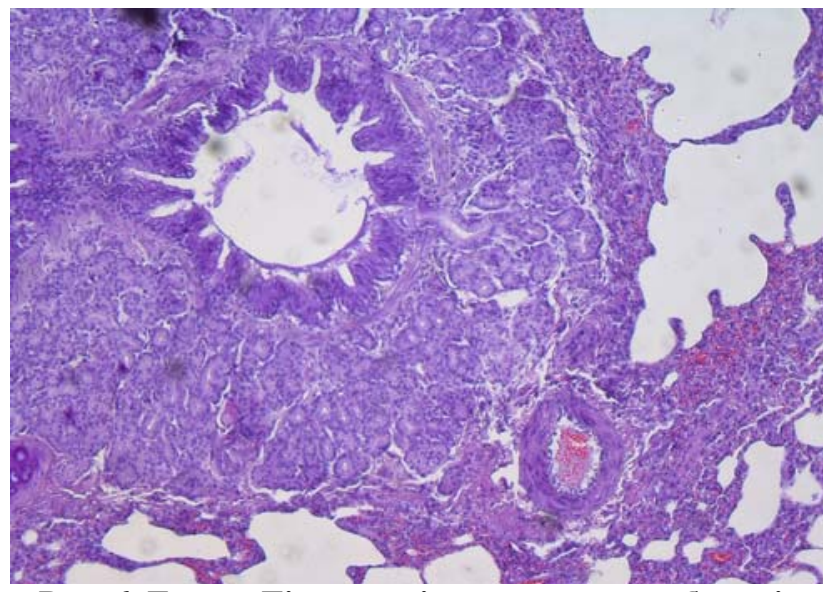

Рис. 6. Бронх. Гіперплазія серомукозних бронхіальних залоз. Гематоксилін та еозин. Ок.10, об. 20

гомеостазу, міграції клітин крові у судинну стінку, тромбоутворення, фібриноліз і багато інших процесів. Ендотеліальні клітини першими стикаються з вільними радикалами, вірусами, тощо, що веде до їх пошкодження та дисфункції (Rojtberg andStrutynskij, 2007).

У стінках артеріальних судин цілісність еластичної мембрани порушена, простежувалось нагромадження кислих глікозаміногліканів, деструкція волок- 
нистих структур, розвиток мукоїдного і фібриноїдного набухання. Слід зазначити, що у більшості стінок артерій виявляли інфільтрацію клітинними елементами середнього шару, що вказувало на розвиток мезоартериїту. Паралельно з цим виявляли навколо артеріол та артерій середнього калібру формування клітинних інфільтратів, в клітинному складі яких переважа-

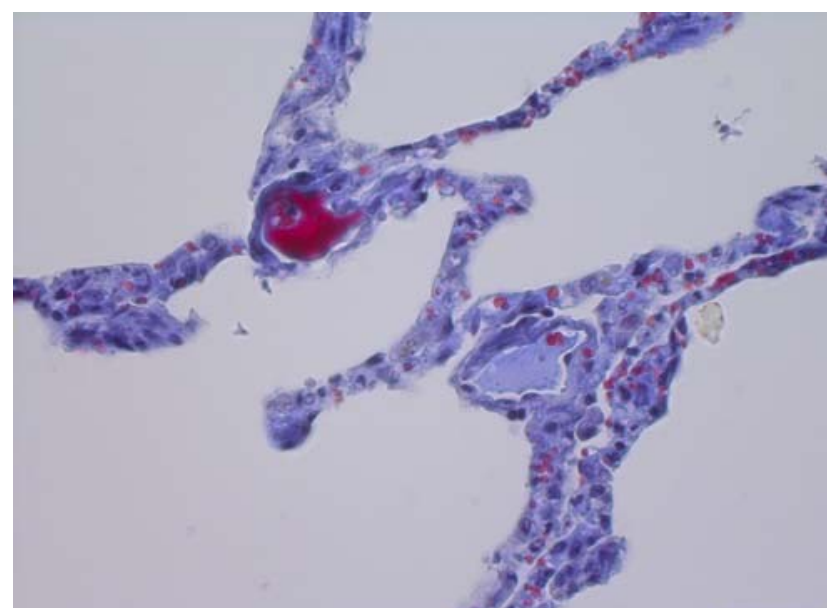

Рис. 7. У просвіті венул гемолізовані еритроцити та плазма.

Зербіно-Лукасевич. Ок.10, об. 40

Часто периартеріальні клітинні інфільтрати на поперечному розрізі судин проглядались у вигляді потужних муфт і нагадували лімфатичні вузлики селезінки (рис. 9). Стінки судин розволокненні, місцями гомогенні, що зрозуміло вело до зниження і пригнічення гемоциркуляції в легенях та трансорганного

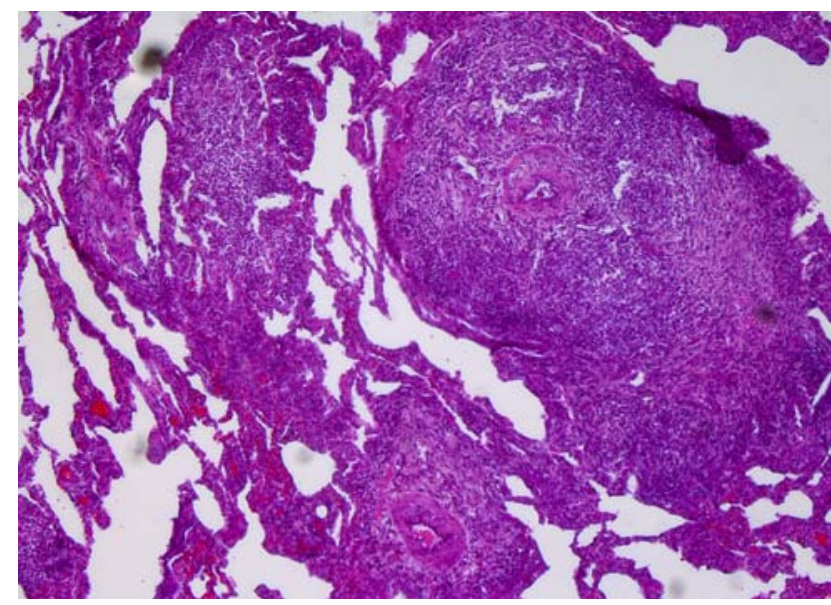

Рис. 9. Легені. Неспецифічні гранульоми навколо артеріол.

Гематоксилін та еозин. Ок.10, об. 10

Аналізуючи патоморфологічні зміни в легеневій тканині спонтанно хворих котів, слід зазначити, що поступове прогресування гемодинамічного порушення кровотоку легень зниження адаптаційних можливостей, зумовило незворотні зміни гомеостазу і розвитку гіпоксії. Адже, пролонговане пригнічення гемоциркуляції в легенях у таких умовах супроводжувалось обтурацією просвітів капілярів еритроцитарними агрегатами, що виводило такі ділянки легень із газообміну. Крім цього виявлений нами синдром ди- ли макрофаги і лімфоцити. За такого розвитку змін, стінки артеріол значно потовщувались, їх просвіт звужувався, часто облітерувався (рис. 8). Слід зазначити, що в легенях превалювала мононуклеарномакрофагальна інфільтрація, особливо в периартеріальній зоні артеріальних судин, що вказувало на прогресування продуктивно--некротичних васкулітів.

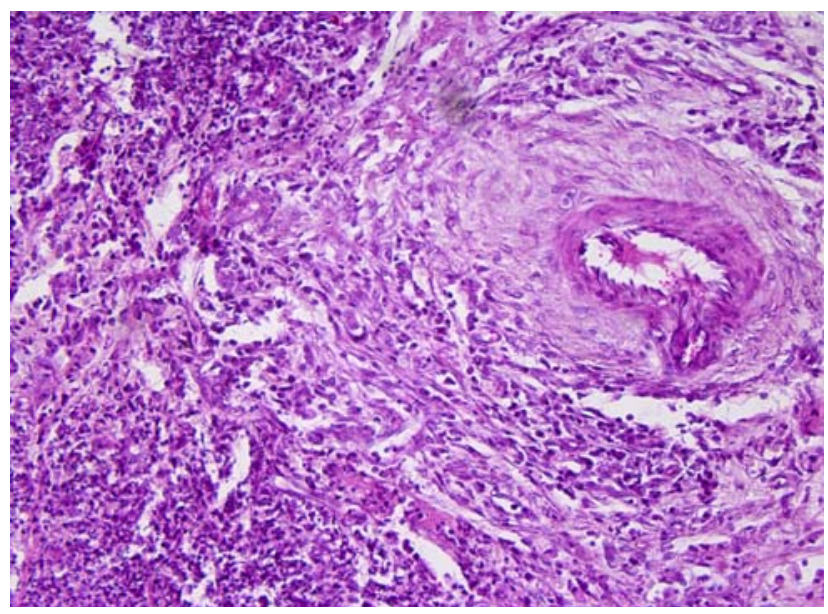

Рис. 8. Артеріола. Периартериїт. Гематоксилін та еозин. Ок.10, об. 20

кровотоку, тобто дефіциту легеневого кровообігу i гіпоксії. Крім того в артеріолах, на препаратах забарвлених за методом Зербіно-Лукасевич, серед клітинних елементі виявляли голубуваті нитки фібрину, мікротромби, що вказувало на розвиток дисемінованого тромбозу судин (рис. 10).

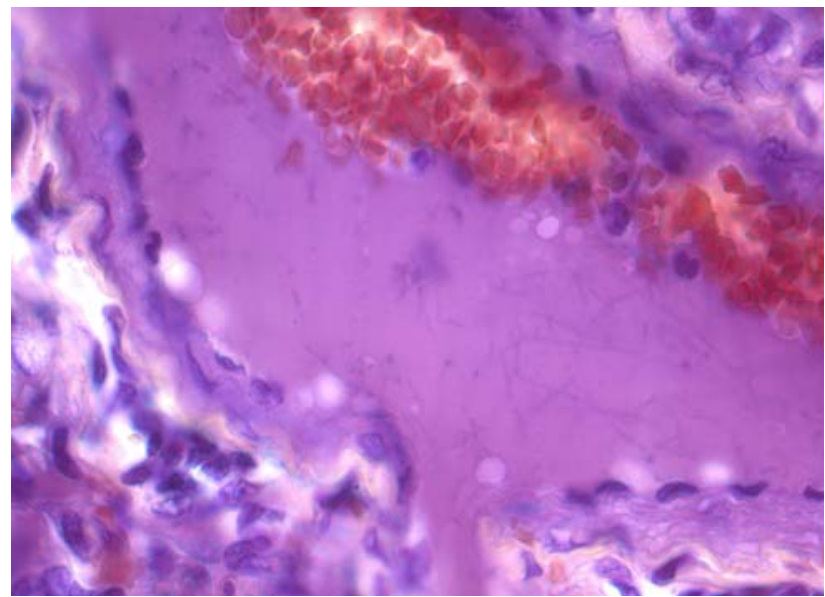

Рис. 10. Артеріола. Нитки фібрину в просвіті судини. Зербіно-Лукасевич. Ок.10, об. 40

семінованого внутрішньосудинного згортання крові - неспецифічний загально-патологічний процес, зумовлений надходженням у кровообіг активаторів коагуляції крові й агрегації тромбоцитів. Відомо, що 3 розвитком внутрішньосудинної коагуляції в кровотоку утворюються множинні мікротромби, які ведуть до блокади мікроциркуляції в органах, розвитку емболів і геморагії, а це в свою чергу до гіпоксії, ацидозу, дистрофічних змін (Rojtberg andStrutynskij, 2007). 
В даному випадку активатором коагуляції крові $є$ вірус FIP. Вірус попадаючи у кров'яне русло генерує активність тканинного фактору в фагоцитах, ендотеліальних і тканинних клітинах, тобто ініціює коагуляційний каскад. За участю активованих тромбоцитів тканинний тромбопластин продукується також пошкодженим ендотелієм судин внаслідок імунного i імунокомплексного ураження, пошкодження ендотелію токсинами, продуктами гемолізу. Внаслідок активації каскаду в кровообігу появляється тромбін, що спричинює перетворення фібриногену на фібрин, незворотну агрегацію тромбоцитів і еритроцитів (Levi et al., 1999; 2013).

\section{Висновки}

У легеневій тканині спонтанно хворих котів за ексудативної форми інфекційного перитоніту за патоморфологічного дослідження встановлено гемодинамічні порушення, інтерстиціальну пневмонію, ателектатичні і емфізематозні осередки та фібринозний плеврит в стані організації. Найбільш важкі зміни розвивались в структурах судинної системи, які характеризувались пошкодженням ендотелію судин, розвитком продуктивного мезо- і периартериїту, дисемінованим тромбозом, стазами і гемолізом еритроцитів в дрібних судинах міжальвеолярних перегородок. Виявлені процеси в судинній системі легеневої тканини зумовили пригнічення гемоциркуляції, незворотні зміни гомеостазу, різке зниження адаптаційних можливостей і порушення трансорганного кровообігу.

\section{Бібліографічні посилання}

Gyl'mutdynov, R.Ja., Yvanov, A.V., Panyn, A.N. (2010). Ynfekcyonnyyj perytonyt koshek. Ynfekcyonnyye bolezny эkzotycheskyh y dykyh zhyvotnyyh. M.: Kolos. 105-106 (in Russian).

Benetka, V., Kübber-Heiss, A., Kolodziejek, J., Nowotny, N., Hofmann-Parisot, M., and Möstl, K. (2004). «Prevalence of feline coronavirus types I and
II in cats with histopathologically verified feline infectious peritonitis», Veterinary Microbiology. 99, $1,31-42$.

Goodson, T.L., Randell, S.C., and Moor, L.E. (2009). «Feline infectious peritonitis», Compendium. 31, pp. 1-9.

Hartmann, K. (2005). «Feline infectious peritonitis». Veterinary Clinics of North America: Small Animal Practice. 35, 1, pp. 39-79.

Pedersen, N.C. (1995). An overview of feline enteric coronavirus and infectious peritonitis virus infections. Feline Practice. 23, 7-20.

Sparkes, A.H., Chandler, E.A., Gaskell, C.J., and Gaskell R.M. (2004). Feline coronavirus infection," in Feline Medicine and Therapeutics. Eds. 623-634, Blackwell publishing, Oxford, UK, 3rd edition.

Zon, G.A., Skrypka, M.V., Ivanivs'ka L.B. (2009). Patologoanatomichnyj roztyn tvaryn. Donec'k. 189 (in Ukrainian)

Merkulov, G.A. (1969). Kurs patogistologicheskoj tehniki. L.: Medicina. 423 (in Russian).

Goral's'kyj, L.P., Homych, V.T., Konons'kyj, O.I. (2011). Osnovy gistologichnoi' tehniky i morfofunkcional'ni metody doslidzhennja $u$ normi ta pry patologii'. Zhytomyr: Polissja. 288. (in Ukrainian).

Zerbino, D.D., Lukasevich, L.L. (1984). Metodika dlja opredelenija vozrasta fibrina pri sindrome disseminirovannogo vnutrisosudistogo svertyvanija krovi // Arhiv patologii. 8, 72-75. (in Russian).

Rojtberg, G.E., Strutynskij, A.V. (2007). Vnutrennie bolezni. Serdechno-sosudistaja sistema. M.: Binompress, 856. (in Russian).

Levi, M.D., Hugo ten Cate, M.D,. Engl N. (1999). Disseminated Intravascular Coagulation. Marcel. Med 341, 586-592.

Levi, M., Hoffman, R, Benz, E. J., Silberstein L.E. et al. (2013). Disseminated intravascular coagulation. Hematology: Basic Principles and Practice. 6th ed. Philadelphia, PA: Elsevier Saunders; 141.

Стаття надійшла до редакиії 10.09.2016 